\title{
The influence of nutrition, maturity and canopy density on the incidence of apple bitter rot
}

\author{
K.R. Everett ${ }^{1}$, O.E. Timudo-Torrevilla ${ }^{1}$, R.W.A. Scheper ${ }^{2}$, P.W. Shaw ${ }^{3}$, P.N. Wood ${ }^{2}$, \\ D.C. Mundy ${ }^{4}$ and D.R. Wallis ${ }^{3}$ \\ ${ }^{1}$ The New Zealand Institute for Plant \& Food Research Limited, \\ Mt Albert Research Centre, Private Bag 92169, Mt Albert, Auckland 1142 \\ ${ }^{2}$ Havelock North Research Centre, Private Bag 1401, Havelock North \\ ${ }^{3}$ Riwaka Research Centre, PO Box 220, Motueka \\ ${ }^{4}$ Marlborough Research Centre, Private Bag 1007, Blenheim \\ Corresponding author: kerry.everett@plantandfood.co.nz
}

\begin{abstract}
Royal Gala' apple fruit were inoculated with Colletotrichum acutatum (the cause of apple bitter rot) conidia at monthly intervals throughout the season in three growing regions in New Zealand. The resultant lesion size was measured on harvested fruit after 9 weeks of coolstorage to generate a disease curve. Nutrient composition, Brix, and mean weight of uninoculated fruit were measured at monthly intervals. The canopy density of the trees at harvest was also determined. These results were compared with the area under the disease curve (AUDC lesion-size days). Starch pattern index and fruit weight at harvest were positively correlated with AUDC, suggesting that fruit towards the end of the season was more susceptible to infection by $C$. acutatum. Nitrogen was also positively correlated with AUDC. Canopy density, potassium and boron were negatively correlated, although the relationship with potassium needs confirmation. There was no relationship of apple bitter rot with calcium.
\end{abstract}

Keywords Potassium, boron, nitrogen, starch pattern index, fruit weight, canopy density, field trials, Colletotrichum acutatum

\section{INTRODUCTION}

The Colletotrichum acutatum species complex causes bitter rot of apples, a disease that usually affects the side of the fruit (Sutton 2014). Historically in New Zealand, apple bitter rot was reported to be caused by Colletotrichum gloeosporioides species complex (Brook 1977), but more recently the causal organism isolated most frequently has been C. acutatum
(Johnston et al. 2005; Everett et al. 2015). Several trials have been conducted to determine the best time to apply fungicides to control apple bitter rot in New Zealand (Everett et al. 2007a; Everett et al. 2015). However, other orchard factors are known to influence apple bitter rot. In a study on avocado fruit rots, which are caused by a complex of fungi that includes C. acutatum (Hartill 1991), it was shown that 
fungicide applications, canopy density and calcium content of the fruit influenced rot incidence (Everett et al. 2007b). Later it was shown that the implementation of canopy management and a good nutrition programme can reduce the incidence of avocado fruit rots (Everett et al. 2008).

In apples, many studies have been conducted on the effect of calcium on bitter pit, a physiological disorder related to insufficient calcium. Nutritional studies with rots as the primary focus are fewer. They showed that calcium, as well as magnesium, nitrogen, potassium, phosphorous and boron (Edney 1976; Sharples 1985; Gagnard 1987; Khalifa et al. 2009; Lysiak 2013; Amiri et al. 2008 ) influenced the incidence of fruit rots.

The influence of tree canopy density on the incidence of rots has not been studied extensively for apples. Summer pruning was shown to increase the prevalence of postharvest rots such as black rot and white rot caused by Botryosphaeria obtusa and $B$. dothidea respectively, by releasing inoculum from the canopy during pruning (Cooley \& Autio 2011). This practice was therefore not recommended for heavily infected orchards. However, on orchards with less disease pressure, the decrease of canopy density that resulted from summer pruning also resulted in a decline of apple fruit rot incidence. On other crops, such as grapes, avocados and kiwifruit, a clear inverse relationship has been shown between canopy density and disease incidence (Gubler et al. 1987; Carroll \& Wilcox 2003; Everett et al. 2007b; Manning et al. 2010; Austin et al. 2011), where pruning reduces rots whether disease pressure is low or high.

Fruit maturity has also been linked to susceptibility of apples to some fruit rot diseases. For example, increasing fruit maturity also increases their susceptibility to Penicillium expansum and Neofabraea alba (Edney 1974; Vilanova et al. 2014). For Neofabraea alba, the increase in susceptibility was hypothesised to be related to a breakdown of inhibitory phenolic compounds as the fruit matured (Edney 1974).

This study reports on the influence of nutrients, fruit maturity and canopy density on the severity of apple bitter rot caused by C. acutatum on 'Royal Gala' apples grown in three regions of New Zealand.

\section{MATERIALS AND METHODS Orchards sampled}

Six 'Royal Gala' apple orchards were selected from three growing districts in New Zealand: Hawke's Bay (HBLR and HBO), Waikato (WD and WA) and Nelson (NW9 and NJ3). HBO was an organic orchard, while the other five were conventional orchards. Ten trees per orchard were selected and identified with labels.

\section{Inoculations}

Fruit and flowers were artificially inoculated with C. acutatum at monthly intervals from flowering (October/September) to harvest (February) during the 2005/06 season, (Table 1). Inoculum was prepared by washing a 2 week-old culture of C. acutatum (ICMP 20568), grown on Difco ${ }^{\circledR}$ potato dextrose agar, with sterile deionised water

Table 1 Dates of Colletotrichum inoculations and apple harvest for the three regions studied during 2005/06.

\begin{tabular}{|c|c|c|c|c|}
\hline & & \multicolumn{3}{|c|}{ Region } \\
\hline & & Waikato & Hawkes' Bay & Nelson \\
\hline \multirow{5}{*}{  } & October & 18 & $5,7,26$ & 11 \\
\hline & November & 17 & 15 & 16 \\
\hline & December & 13 & 12 & 14 \\
\hline & January & 20 & 17 & 18 \\
\hline & February & 17 & 13 & 15 \\
\hline Harvest & & March 6 & February 20 & March 1 \\
\hline
\end{tabular}


(SDW). The concentration of the resultant conidial suspension was adjusted with SDW and with the aid of a haemocytometer. Inoculations were carried out by wounding sepals of flowers and the side of fruit with a needle to a depth of $5 \mathrm{~mm}$, then spraying with a conidial suspension $\left(10^{6}\right.$ spores $\left./ \mathrm{ml}\right)$ or with SDW (un-inoculated controls). Five fruit from each of 10 trees in each of the six orchards were treated with water or conidial suspension.

Following harvest in February or March 2006, the fruit were placed in cool stores at $0.5 \pm 0.5^{\circ} \mathrm{C}$ and assessed for rots after 9 weeks. Rots were assessed by measuring the lesion size (mean of two measurements at right angles to each other).

\section{Area under the disease curve}

The area under the disease curve (AUDC) was calculated for each orchard where the $\mathrm{x}$ axis was the month that the flowers or fruit were inoculated (days), and the y axis was mean lesion diameter (mean lesion size), using the method described by Madden et al. (2007). Data were expressed as mean lesion size-days. The AUDC resulting from inoculations with water was subtracted from the inoculated AUDC to remove the effect of any background disease infections. The AUDC for number of infected fruit was calculated the same way, but these data were not presented.

\section{Canopy density}

A photograph was taken with a Nikon D70 camera with a $20-80 \mathrm{~mm}$ lens from the base of every tree with the camera pointed skywards in each study orchard. The photographs were analysed using the ASSESS image analysis programme (American Phytopathological Society) to give an estimate as a percentage of the amount of canopy compared with sky in each photograph. A mean canopy density based on canopy photographs of 10 trees was calculated for each orchard.

\section{Nutritional analysis}

Fifty fruit that were not inoculated were sampled from the same trees on which fruit were inoculated from each orchard at monthly intervals and stored at $-20^{\circ} \mathrm{C}$. In March, fruit were processed for nutritional analysis by Hill Laboratories (R. J. Hill Laboratories Ltd, Hamilton). Whole fruit were used for the analysis. Samples were oven-dried at $62^{\circ} \mathrm{C}$ over three nights and ground to a particle size capable of passing through a $1.0 \mathrm{~mm}$ screen. Tests were performed on a dry matter basis but reported on a fresh weight basis. Samples were subjected to Nitric/Perchloric acids digestion followed by inductively-coupled plasma optical emission spectroscopy (ICP-OES analysis) to identify individual elements. The nitrogen content was determined by Dumas combustion. Fruit were analysed for calcium $(\mathrm{Ca})$, potassium $(\mathrm{K})$, magnesium $(\mathrm{Mg})$, phosphorus $(\mathrm{P})$, sulphur $(\mathrm{S})$, sodium $(\mathrm{Na})$, iron $(\mathrm{Fe})$, manganese $(\mathrm{Mn})$, zinc $(\mathrm{Zn})$, copper $(\mathrm{Cu})$, boron $(\mathrm{B})$ and nitrogen $(\mathrm{N})$ content.

\section{Starch and sugar content}

Every month (except for November when fruit were too immature for juice to be extracted) 20 fruit per orchard were tested for sugar content (Brix) using a refractometer (Atago N10 or N20) and starch pattern index according to the methodology described in the ENZA Fruit Maturity Procedures Manual (including a severity chart).

\section{Spray diary information}

Producers on each orchard maintain records in a spray diary of insecticide and fungicide sprays applied to the trees. Spray diary data was obtained from each orchard.

\section{Statistical analysis}

The generalised linear model and linear regression functions of $\mathrm{Minitab}^{\circledR}$ and Microsoft ${ }^{\circledR}$ Excel were used for data analysis. Graphs were generated using Microcal ${ }^{\circledR}$ Origin. The individual minerals and $(\mathrm{Mg}+\mathrm{K}) / \mathrm{Ca}, \mathrm{K} / \mathrm{Ca}$ and $\mathrm{N} / \mathrm{Ca}$ ratios were compared with AUDC using linear regression and an $\mathrm{R}^{2}$ value calculated when $\mathrm{P}$ for linear regression analysis was $<0.05$. The AUDC mean lesion size-days value was logarithmically transformed to improve the fit of the data for comparison with 

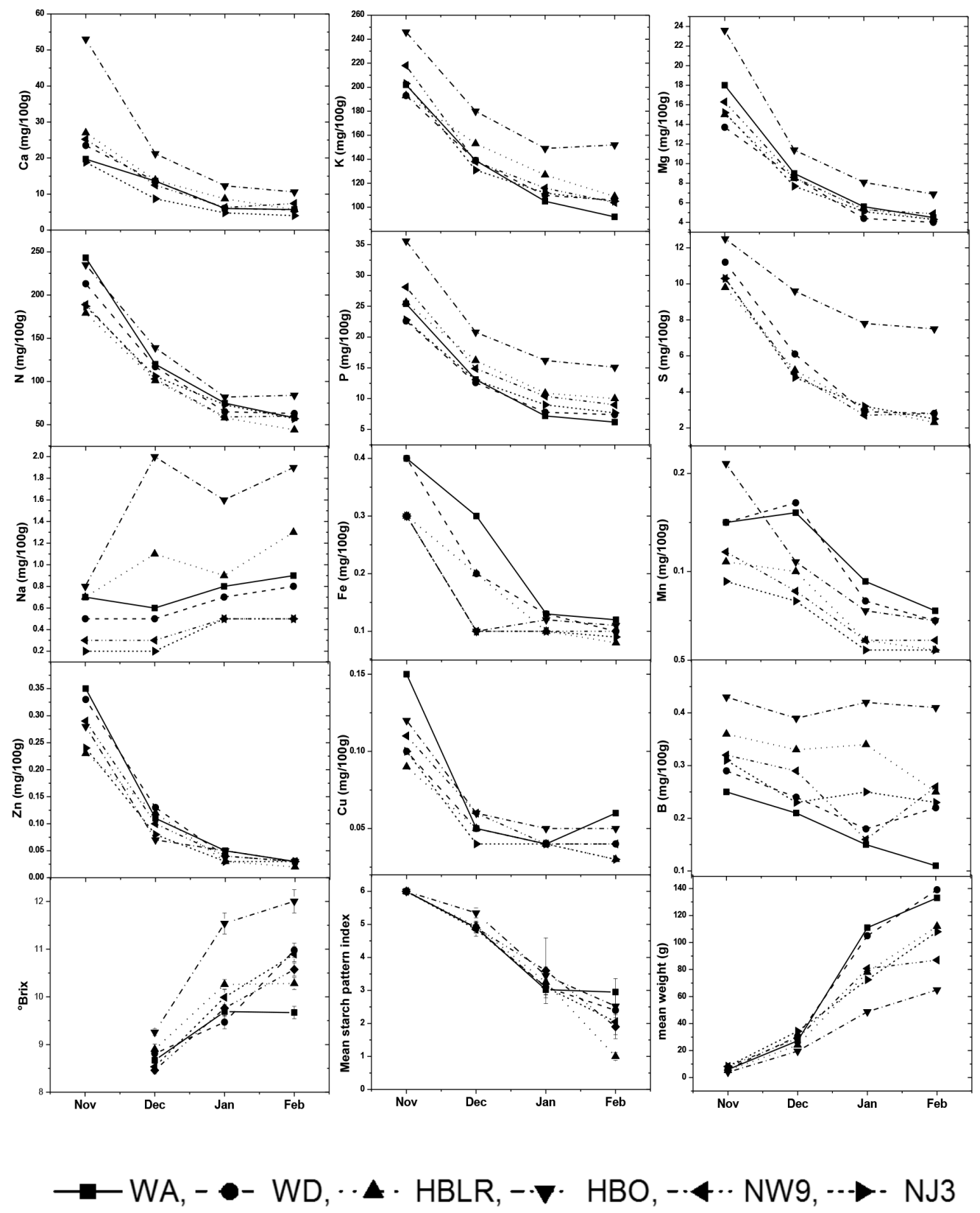

Figure 1 Changes in nutrient composition, ${ }^{\circ}$ Brix, starch pattern index and mean weight for uninoculated apple fruit sampled from three regions in New Zealand (Waikato; WA and WD, Hawke's Bay; HBLR and HBO, Nelson; NW9 and NJ3) at monthly intervals throughout the 2005/06 season. $\mathrm{N}=50$. 
Table 2 Nutrient content (mg/100 g fresh weight) of apples sampled at harvest from Waikato (WA, WD), Hawke's Bay (HBLR, HBO) and Nelson (NW9, NJ3), and area under the disease curve (AUDC; mean lesion-size days) for lesions on apple fruit inoculated in the orchard monthly and assessed postharvest after 9 weeks coolstorage.

\begin{tabular}{lcccccc}
\hline \multirow{2}{*}{ Nutrient } & \multicolumn{7}{c}{ Orchards from which apples were sampled } & \\
\hline $\mathrm{Ca}$ & WA & WD & HBLR & HBO & NW9 & NJ3 \\
$\mathrm{K}$ & 4.2 & 5.3 & 5.7 & 10.6 & 6.1 & 3.4 \\
$\mathrm{Mg}$ & 93 & 107 & 109 & 152 & 107 & 104 \\
$\mathrm{~N}$ & 4 & 4 & 4.3 & 6.9 & 7.1 & 4.2 \\
$\mathrm{P}$ & 66 & 61 & 44 & 84 & 55 & 61 \\
$\mathrm{~B}$ & 6.6 & 7.3 & 10 & 15.1 & 13.6 & 7.6 \\
$\mathrm{~N} / \mathrm{Ca}$ & 0.14 & 0.2 & 0.25 & 0.41 & 0.24 & 0.2 \\
$\mathrm{~K} / \mathrm{Ca}$ & 15.7 & 11.5 & 7.7 & 7.9 & 9.0 & 17.9 \\
$\mathrm{Ca}+\mathrm{Mg} / \mathrm{K}$ & 22.1 & 20.2 & 19.1 & 14.3 & 17.5 & 30.6 \\
$\mathrm{AUDC}$ & 0.088 & 0.087 & 0.092 & 0.115 & 0.123 & 0.073 \\
\hline
\end{tabular}

the starch pattern index and nitrogen content.

\section{RESULTS}

Fruit calcium content at harvest ranged from 3.4 to $10.6 \mathrm{mg} / 100 \mathrm{~g}$, with two orchards below 4.5 (Table 2). Potassium ranged from 93 to $152 \mathrm{mg} / 100 \mathrm{~g}$, magnesium from 4 to $7.1 \mathrm{mg} / 100 \mathrm{~g}$, nitrogen from 44 to $84 \mathrm{mg} / 100 \mathrm{~g}$, phosphorous from 6.6 to 15.1 $\mathrm{mg} / 100 \mathrm{~g}$, and boron from 0.2 to $0.41 \mathrm{mg} / 100 \mathrm{~g}$. The ratio of N/Ca ranged from 7.7 to 17.9, of K/Ca from 14.3 to 30.6 , and $(\mathrm{Ca}+\mathrm{Mg}) / \mathrm{K}$ from 0.073 to 0.123 .

The concentrations of $\mathrm{Ca}, \mathrm{K}, \mathrm{Mg}, \mathrm{N}, \mathrm{P}, \mathrm{S}, \mathrm{Fe}$, $\mathrm{Mn}, \mathrm{Zn}, \mathrm{Cu}$ and the starch pattern index (SPI) in fruit from all orchards declined during the season (Figure 1). Concentrations of $\mathrm{Na}$, Brix and mean weight (MW) increased in fruit from all orchards during the season. Boron concentrations decreased during the season in all orchards except HBO.

Fruit from the organic orchard (HBO) were the smallest of all fruit sampled, heavily infected with black spot (Venturia inaequalis), and highest in $\mathrm{Ca}, \mathrm{K}, \mathrm{Mg}, \mathrm{N}, \mathrm{P}, \mathrm{S}, \mathrm{Na}$ and B content (Figure 1).

Lesion size measured after 9 weeks of coolstorage was greatest for those fruit inoculated in January (Figure 2). Fruit that had the greatest severity of apple bitter rot were sourced from orchards in the Waikato district
(WA), and those that showed the least severity were from Hawke's Bay (HBLR) (Table 2). There were no statistically significant relationships between AUDC for incidence data and nutrition, maturity indices (SPI and Brix) or MW. There was a statistically significant relationship between AUDC lesion-size days (severity data) and canopy density, SPI and N for all six orchards (Figure 3a, $\mathrm{b}$ and $\mathrm{d}$ ). There was also a significant relationship between AUDC for incidence data and canopy density $\left(R^{2}=69 \%, P=0.04\right)$. However, only when the data from the apples grown under an organic programme (HBO), which is managed differently to the five conventionally managed orchards, were removed from the analysis was there a significant relationship between AUDC lesion-size days and MW, $\mathrm{K}$ and $\mathrm{B}$ (Figure $3 \mathrm{~b}$, e and $\mathrm{f}$ ). The missing data for the organic orchard were an AUDC of 1537.26 mean lesion size-days and 64.9 g MW, 152 $\mathrm{mg} / 100 \mathrm{~g} \mathrm{~K}$, and $0.41 \mathrm{mg} / 100 \mathrm{~g} \mathrm{~B}$. The MW, K and B values were off the scale used for the analysis of the five conventional orchards (Figure $3 c$, e and $\mathrm{f}$ ). The relationship between AUDC lesion size-days and SPI, MW and $\mathrm{N}$ was positive, and negative with canopy density, $\mathrm{K}$ and $\mathrm{B}$. There were significant interactions between B and N, B and K, MW and 


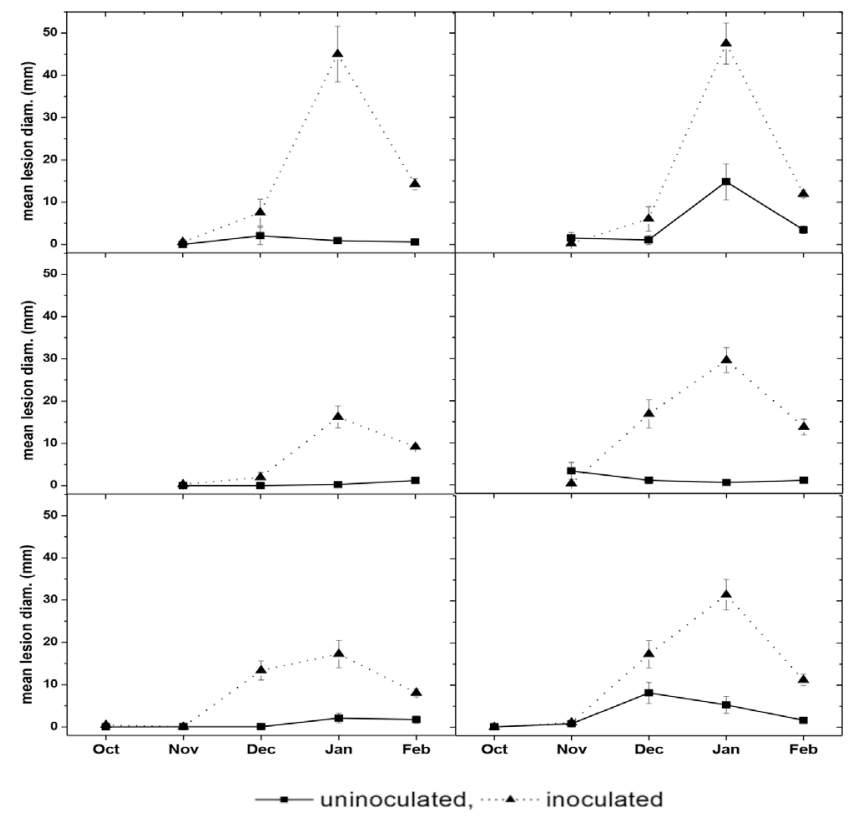

Figure 2 Mean lesion size $(\mathrm{mm})$ of infections following monthly wound-inoculatiion of apple fruit or flowers with Colletotrichum acutatum or water in six orchards from October to February and postharvest assessment after storage for 9 weeks at $0^{\circ} \mathrm{C}$. Orchards, left to right, top to bottom, are WA, WD, HBLR, HBO, NW9 and NJ3. Area under the disease curve (AUDC) was calculated for analysis. $\mathrm{N}=50$.

Table $3 \mathrm{R}^{2}$ values from linear regression analysis between various factors influencing Colletotrichum disease in apples, 2005/06. Disease was calculated from the area under the disease curve (AUDC mean lesion size-days) for apples inoculated at monthly intervals with $10^{6}$ conidia/ml of C. acutatum.

\begin{tabular}{lllllll}
\hline & $\mathrm{K}$ & $\mathrm{N}$ & $\mathrm{MW}$ & $\mathrm{B}$ & $\mathrm{SPI}$ & $\mathrm{CD}$ \\
\hline $\mathrm{K}$ & & & & & \\
$\mathrm{N}$ & n.s. & & & & \\
$\mathrm{MW}$ & n.s. & $+95 \%$ & & & \\
$\mathrm{~B}$ & $+86 \%$ & $-77 \%$ & n.s. & & \\
SPI & n.s. & n.s. & $+86 \%$ & n.s. & \\
CD & n.s. & n.s. & n.s. & n.s. & n.s. &
\end{tabular}

Mean lesion size-days $-79 \%+87 \%$ $+87 \%$ $-96 \%+71 \%$ * $-64 \%$ ${ }^{*} \mathrm{n}=6$; for all other correlations $\mathrm{n}=5$ (HBO was not included), n.s. = not significant, $\mathrm{K}=$ potassium, $\mathrm{N}=$ nitrogen, $\mathrm{MW}=$ mean weight, $\mathrm{B}=$ boron, $\mathrm{SPI}=$ starch pattern index, $\mathrm{CD}=$ canopy density 




(b)



(c)

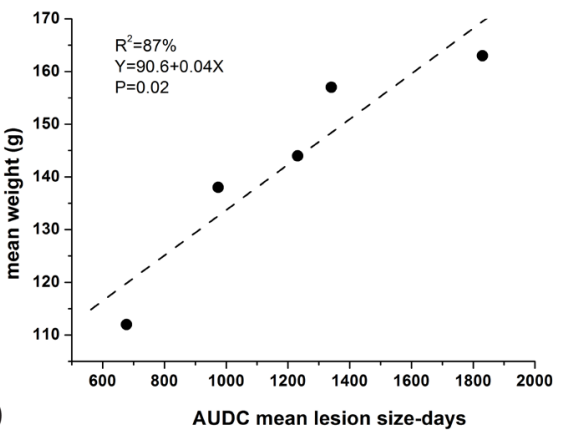

(d)
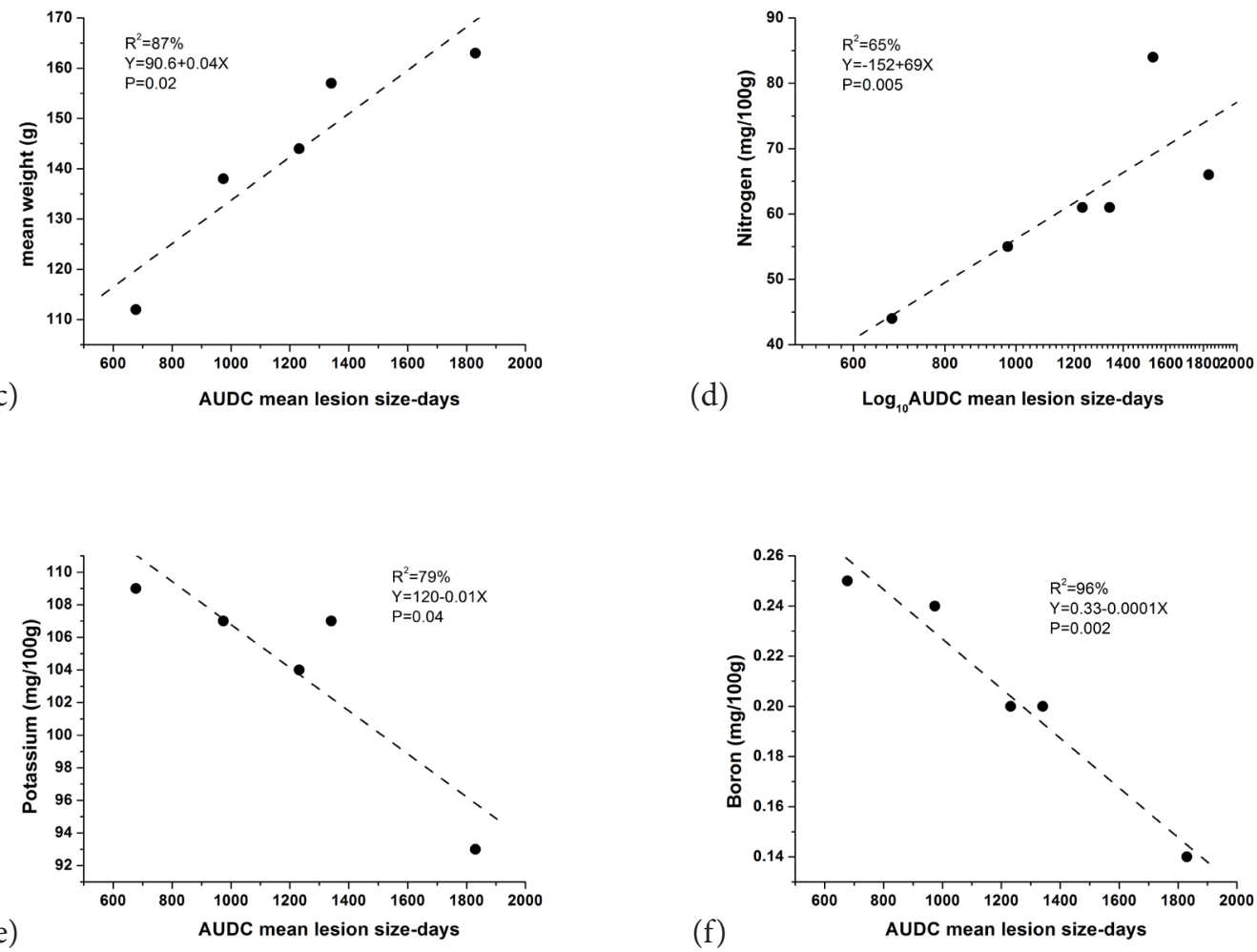

Figure 3 Area under the disease curve (AUDC mean lesion size-days) for the orchards plotted against (a) canopy density (\%), (b) starch pattern index (SPI), (c) mean weight, (d) nitrogen (N), (e) potassium $(\mathrm{K})$ and (f) boron (B) assessed at harvest. All six orchards were included for the analysis of N, canopy density and SPI, but the organic orchard (HBO) was removed from the analysis of $\mathrm{B}, \mathrm{K}$ and mean weight due to lack of fit. The missing data for HBO were an AUDC of 1537.26 mean lesion size-days and 64.9g MW, $152 \mathrm{mg} / 100 \mathrm{~g} \mathrm{~K}$, and $0.41 \mathrm{mg} / 100 \mathrm{~g} \mathrm{B.}$ 
$\mathrm{N}$, and between MW and SPI (Table 3). No other relationships were found with any other factor analysed, including $\mathrm{N} / \mathrm{Ca}, \mathrm{K} / \mathrm{Ca}$ and $(\mathrm{Ca}+\mathrm{Mg}) / \mathrm{K}$.

There was no obvious relationship between the fungicides that were applied and differences in disease between the six orchards studied.

\section{DISCUSSION}

There were significant correlations between severity of disease on fruit wound-inoculated with C. acutatum in the orchards studied and canopy density, K, N, B, Starch Pattern Index (SPI), and Mean Weight (MW) assessed at harvest. Fruit from the organically managed orchard were correlated with those from the conventionally managed orchards when canopy density, SPI and N were compared with disease severity, but not when MW, $\mathrm{K}$ and $\mathrm{B}$ were compared. For these parameters, fruit from organically managed orchards were too dissimilar to those from conventionally managed orchards to enable any trends to be identified from only one organic orchard included in this study. The reason for this disparity requires further study.

SPI has been shown to be a reliable indicator of fruit maturity (Smith et al. 1979). MW was highly correlated with SPI for fruit from conventionally managed orchards, suggesting that for these orchards MW was also related to fruit maturity. Fruit maturity may have a role in disease incidence; Brook (1977) observed that apples did not show symptoms of apple bitter rot caused by C. gloeosporioides until fruit were approaching maturity. Increasing maturity resulted in higher incidence of Penicillium expansum (blue mould) (Vilanova et al. 2014) and Neofabraea alba (Bull's eye rot) (Edney 1974) in apples. However, preliminary work has shown that $C$. acutatum will infect immature apples when the temperature is above ca $15^{\circ} \mathrm{C}$ (Everett et al. 2009). Only late in the 'Royal Gala' apple season do mean daily temperatures exceed $15^{\circ} \mathrm{C}$, therefore the correlation with maturity indicators may simply be that temperatures are suitable for infection late in the season when fruit are more mature.

Nitrogen $(\mathrm{N})$ at harvest was positively correlated with disease severity. High fruit $\mathrm{N}$ content has been implicated in disease incidence of apple fruit rots caused by other organisms (Bull's eye rot, blue mould and brown rot) (Sharples 1985; Lysiak 2013). Increased N concentration may result in weaker cell walls in the fruit and thus greater susceptibility to fungal pectolytic enzymes (Bateman \& Basham 1976 ).

In contrast, $\mathrm{B}$ and $\mathrm{K}$ were inversely correlated with disease severity. K deficiency has been defined as fruit concentrations of $<100 \mathrm{mg} / 100 \mathrm{~g}$ fresh weight (Neilsen et al. 2004) and for fruit from five orchards $\mathrm{K}$ was very close to this concentration. However, Hunsche et al. (2003) found no reduction in storage rots from 9 years of applying potassium fertilisers to the soil. In contrast, Sharples (1985) showed that high concentrations of $\mathrm{K}$ increased the incidence of Bull's eye rot in two of seven seasons. Lysiak (2013) showed that $\mathrm{N}, \mathrm{K}$ and Mg were all positively correlated with rot incidence, and that $\mathrm{P}$ and $\mathrm{Ca}$ were negatively correlated. Although total disease (Bull's eye rot, blue mould and brown rot) was positively correlated to K, diseases analysed separately were both positively (Bull's eye rot and brown rot) and negatively (blue mould) correlated, although only the relationship with Bull's eye rot was significant. There may be disease specific responses to $\mathrm{K}$ dependent on the infection strategy employed by the pathogen. Bitter rot is most likely to be similar to Bull's eye rot and brown rot, which are able to infect unwounded apples, but not to Penicillium (blue mould), which is a wound pathogen. Boron was not tested in this latter study. However, our results may have been unduly influenced by one data point (WA, $\mathrm{K}=93 \mathrm{mg} / 100 \mathrm{~g}$ ), and although significant, the relationship requires more investigation by examining more orchards.

The concentrations that define B deficiency in fruit were not found in the literature. However, it is likely that B deficiency was a factor in this trial, and certainly a higher concentration of B in fruit resulted in less severe rot lesions. Similarly, leaf concentration of B in peaches was negatively correlated with the incidence of infections by Monilinia laxa (Thomidis \& Exadaktylou 2010). In contrast, Wojcik et al. (1999) showed that foliar 
B applications to apples in the orchard increased the incidence of Bull's eye rot, but soil application decreased incidence. In agreement with the results from soil application of B, Khalifa et al. (2009) decreased the incidence of apple storage rots caused by botrytis after spraying trees in the orchard with $B$, suggesting that the contrary results may have been due to the formulation or rates of boron that were applied damaging the fruit surface and facilitating fungal invasion.

Because $\mathrm{B}$ and $\mathrm{K}$ were correlated with apple bitter rot severity, it is possible that the apparent effect of $\mathrm{K}$ on fruit rots was because $\mathrm{K}$ affected the amount of $\mathrm{B}$ in fruit, and that $\mathrm{B}$ was the compound that was inhibiting rot development. $\mathrm{B}$ sprays were shown to decrease $\mathrm{K}$ concentrations in apple fruit flesh (Wojcik 1999), showing that uptake of one element affected the other. However, in the present study $\mathrm{B}$ and $\mathrm{K}$ were positively correlated. As the relationship with $\mathrm{K}$ may have been unduly influenced by one datum point, which was opposite to the results for the other apple pathogens, it is likely that only B concentration was important in this study. Examination of the effect of B orchard sprays on bitter rot incidence is required to determine if this can be recommended as a management technique.

Decreasing the canopy density has been shown to reduce the incidence of plant diseases such as botrytis and powdery mildew in grapes (Gubler et al. 1987; Carroll \& Wilcox 2003; Austin et al. 2011), botrytis of kiwifruit (Manning et al. 2010) and fruit rots of avocados (Everett et al. 2007b). This has been largely attributed to not only the influence of canopy density on humidity (Carroll \& Wilcox 2003), but also to fungicide coverage (Austin et al. 2011). Lowering the humidity by reducing canopy density has been shown to reduce spore germination and thus infection of fruit (Carroll \& Wilcox 2003). It is therefore not unexpected that a decrease of apple canopy density is also correlated with a decline in disease incidence (Cooley \& Autio 2011). However, in practice, reducing the apple canopy density also reduces yield (Fallahi et al. 2015). Therefore, it may be more efficient to control apple fruit rots by other means to maximise profits.

It was unexpected that the calcium concentrations were not related to apple bitter rot disease severity in this study. There are several studies on apples (Edney 1976; Sharples 1985; Khalifa et al. 2009; Lysiak 2013; Amiri et al. 2008 ) showing that calcium in fruit is negatively correlated with fruit rots. However, for avocados it was shown that once calcium concentrations had exceeded a threshold, there was no further reduction in rot incidence (Everett et al. 2007a). For avocados the threshold was a $(\mathrm{Ca}+\mathrm{K}) / \mathrm{Mg}$ ratio of 0.065 (Everett et al. 2007a), and in the current study this ratio was higher than 0.073 for apple fruit from all sampled orchards at harvest. The threshold of the $(\mathrm{Ca}+\mathrm{K}) / \mathrm{Mg}$ ratio after which there is no further improvement in quality with respect to apple bitter rot is not known.

The ratio of K/Ca was the best predictor of susceptibility to rots for the 'Ligol' apple variety (Lysiak 2013), and if this ratio was over 20 then the fruit did not store well. This ratio was greater than 20 for three of the orchards in this current study. Other studies showed a relationship between the $\mathrm{N} / \mathrm{Ca}$ ratio and losses during storage (Casero et al. 2010; Amiri et al. 2008 ). None of these ratios was significantly related to AUDC lesion-size days in this study. The optimal concentration of calcium in fruit flesh for Cox's orange is $4.5-5 \mathrm{mg} / 100 \mathrm{~g}$ fresh weight (Gagnard 1987). In this study, fruit calcium at harvest for two orchards was below $4.5 \mathrm{mg} / 100 \mathrm{~g}$ FW. However, in New Zealand the threshold levels ranged between 2.4 and $4.5 \mathrm{mg} / 100 \mathrm{~g}$ FW (Ferguson et al. 1979; Ferguson \& Watkins 1989) for bitter pit, but elsewhere the thresholds were higher, at 3.7-6 mg/100g FW (Benge 1996). Therefore, the calcium concentrations in fruit in this study, although lower than reported elsewhere in relation to susceptibility to rots, may have been sufficient to protect 'Royal Gala' apples grown in New Zealand. There may also be varietal differences in optimal calcium concentrations, as has been reported for bitter pit (Wills et al. 1976).

Calcium has been implicated in reducing the ability of fungi to penetrate the cuticle, possibly by strengthening the cell walls (Conway et al. 1994). Wound-inoculating may have removed this protective effect, which could explain the lack of relationship between calcium and disease severity 
in the current study. Calcium has been shown to be involved as a signalling molecule for initiation of plant defence mechanisms (Du et al. 2009), thus the concentration of calcium in the flesh may also be related to disease resistance. Orchard application of calcium reduced postharvest decay caused by the wound pathogen Penicillium expansum (Wojcik \& Borowik 2013), and enhanced the biocontrol activity of a yeast that colonises its wounds (Vorstermans et al. 2007). These reports suggested that the concentration of calcium in the flesh of apples could also be important for disease control.

Lesion size increased as the season progressed, except for fruit inoculated in February. It is possible that given more time before harvest, the lesions on these fruit would have followed the same pattern, as even after this relatively short time period they were a similar size to the lesions on fruit inoculated in December. January inoculations were 45, 34 and 42 days before harvest for Waikato, Hawke's Bay and Nelson, respectively, whereas harvest was 17, 7 and 14 days after February inoculations.

Results of the present study suggest that maintaining $B$ concentrations in fruit should reduce apple bitter rot severity. The feasibility of foliar application of B in the orchard to control bitter rot requires investigation. Calcium concentrations were below those recommended for control of bitter pit in the literature, but they may have been sufficient for the control of rots caused by apple bitter rot. These results also suggest that the amount of calcium needed to inhibit rot development in apple fruit requires further elucidation.

\section{ACKNOWLEDGEMENTS}

Pipfruit New Zealand, Nelson Group 8, Waikato Fruitgrowers and Sunfruit Orchards for funding, and for allowing us to use apple trees on their orchards.

\section{REFERENCES}

Amiri ME, Fallahi E, Golchin A 2008 Influence of foliar and ground fertilization on yield, fruit quality, and soil, leaf, and fruit mineral nutrients in apple. Journal of Plant Nutrition 31: 515-525.
Austin CN, Grove GG, Meyers JM, Wilcox WF 2011. Powdery Mildew Severity as a Function of Canopy Density: Associated Impacts on Sunlight Penetration and Spray Coverage. American Journal of Enology and Viticulture 62: 23-31.

Bateman D, Basham HG 1976 Degradation of plant cell walls and membranes by microbial enzymes. Encyclopedia of Plant Physiology New Series 4: 316-355.

Benge JR 1996. Orchard practices to enhance pipfruit storage behaviour through calcium and boron nutrition. A review of the literature. Report to the NZ Apple \& Pear Marketing Board. Massey University, Palmerston North. p. 130.

Brook PJ 1977. Glomerella cingulata and bitter rot of apple. New Zealand Journal of Agricultural Research 20: 547-555.

Carroll JE, Wilcox WF 2003. Effects of humidity on the development of grapevine powdery mildew. Phytopathology 93: 1137-1144.

Casero T, Benavides AL, Recasens I 2010. Interrelation between fruit mineral content and pre-harvest calcium treatments on 'golden smoothee' apple quality. Journal of Plant Nutrition 33: 27-37.

Conway WS, Sams CE, Kelman A 1994. Enhancing the natural-resistance of planttissues to postharvest diseases through calcium applications. HortScience 29: 751754.

Cooley DR, Autio WR 2011. Summer pruning of apple: impacts on disease management. Advances in Horticultural Science 25: 199204.

Du L, Ali GS, Simons KA, Hou J, Yang T, Reddy ASN, Poovaiah BW 2009. Ca2+/calmodulin regulates salicylic-acid-mediated plant immunity. Nature 457: 1154-U1116.

Edney KL 1974. Pezicula malicorticis: factors affecting spore germination and invasion of apple fruit. Transactions of the British Mycological Society 62: 25-34.

Edney KL 1976. An investigation of persistent infection of stored apples by Gloeosporium spp. Annals of Applied Biology 82: 355-360. 
Everett KR, Timudo-Torrevilla OE, Taylor JT, Yu J 2007a. Fungicide timing for control of summer rots of apples. New Zealand Plant Protection 60: 15-20.

Everett KR, Boyd LM, Pak HA, Cutting JGM 2007b. Calcium, fungicide sprays and canopy density influence postharvest rots of avocado. Australasian Plant Pathology 36: 22-31.

Everett KR, Pushparajah IPS, Timudo-Torrevilla OE, Manning MA 2008. Orchard treatments other than spray application of fungicides that reduce postharvest rots of avocado. New Zealand Avocado Growers' Association Annual Research Report 8: 93-98.

Everett KR, Pushparajah IPS, Taylor JT, TimudoTorrevilla OE, Spiers TM, Ah Chee A, Shaw PW, Wallis DR 2015. Evaluation of fungicides for control of bitter and sprinkler rots on apple fruit. New Zealand Plant Protection. 68: 264-274.

Everett KR, Timudo-Torrevilla OE, Pushparajah IPS, Scheper RWA, Shaw PW, Spiers TM, Ah Chee A, Taylor JT, P. Wood, Wallis DR, Manning MA 2009. Criteria for infection of apples by Colletotrichum acutatum causing summer rots. The Orchardist August: 24-27.

Fallahi E, Rom CR, Fallahi B, Mahdavi S 2015. Leaf and Fruit Mineral Nutrient Partitioning Influenced by Various Irrigation Systems in 'Fuji' Apple over Four Years. Journal of the American Pomological Society 69: 137-147.

Ferguson IB, Watkins CB 1989. Bitter pit in apple fruit. Horticultural Reviews 11: 289-355.

Ferguson IB, Reid MS, Prasad M 1979. Calcium analysis and the prediction of bitter pit in apple fruit. New Zealand Journal of Agricultural Research 22: 485-490.

Gagnard J 1987. Apples. In: Martin-Prevel P, Gagnard J, Gautier P eds. Plant Analysis. As a guide to the nutrient requirements of temperate and tropical crops Lavoisier Publishing Inc., New York. Pp. 207-229.

Gubler WD, Marois JJ, Bledsoe AM, Bettiga LJ 1987. Control of Botrytis bunch rot of grape with canopy management. Plant Disease 71: 599-601.

Hartill WFT 1991. Postharvest diseases of avocado fruits in New Zealand. New Zealand Journal of Crop and Horticultural Science 19: 297-304.

Hunsche M, Brackmann A, Ernani PR 2003. Effect of potassium fertilization on the postharvest quality of 'Fuji' apples. Pesquisa Agropecuaria Brasileira 38: 489-496.

Johnston PR, Pennycook SR, Manning MA 2005. Taxonomy of fruit-rotting fungal pathogens: what's really out there? New Zealand Plant Protection 58: 42-46.

Khalifa RKM, Omaima MH, Abd-El-Khair $\mathrm{H}$ 2009. Influence of foliar spraying with boron and calcium on productivity, fruit quality, nutritional status and controlling of blossom end rot disease of 'Anna' apple trees. World Journal of Agricultural Sciences 5: 237-249.

Lysiak G 2013. The influence of harvest maturity and basic macroelement content in fruit on the incidence of diseases and disorders after storage of the 'Ligol' apple cultivar. Folia Horticulturae 25: 31-39.

Madden LV, Hughes G, Bosch Fvd 2007. The study of plant disease epidemics. The American Phytopathological Society, St Paul, Minnesota. $421 \mathrm{p}$.

Manning MA, Pak HA, Beresford RM 2010. Non-fungicidal control of botrytis storage rot in New Zealand kiwifruit through pre- and postharvest crop management. In: Prusky D, Gullino ML eds. Plant Pathology in the 21st Century Volume 2. Post-harvest pathology. Springer, Dordrecht Heidelberg London New York. Pp. 183-196.

Neilsen GH, Neilsen D, Herbert LC, Hogue EJ 2004. Response of apple to fertigation of $\mathrm{N}$ and $\mathrm{K}$ under conditions susceptible to the development of $\mathrm{K}$ deficiency. Journal of the American Society for Horticultural Science 129 26-31.

Sharples RO 1985. The influence of preharvest conditions on the quality of stored fruits. Acta Horticulturae: 93-104.

Smith RB, Lougheed EC, Franklin EW, McMillan I 1979. The starch iodine test for determining stage of maturation in apples. Canadian Journal of Plant Science 49: 805-807. 
Sutton TB 2014. Bitter rot. In: Sutton TB, Aldwinckle HS, Agnello AM, Walgenbach JF eds. Compendium of apple and pear diseases and pests. Second edition. The American Phytopathological Society, St. Paul, Minnesota, USA. Pp. 20-21.

Thomidis T, Exadaktylou E 2010. Effect of boron on the development of brown rot (Monilinia laxa) on peaches. Crop Protection 29: 572576.

Vilanova L, Vinas I, Torres R, Usall J, BuronMoles G, Teixido N 2014. Increasing maturity reduces wound response and lignification processes against Penicillium expansum (pathogen) and Penicillium digitatum (non-host pathogen) infection in apples. Postharvest Biology and Technology 88: 5460.

Vorstermans B, van Laer S, Creemers P, Pujos P, Jijakli H 2007. Improving control of storage diseases on apple by combining biological and physical post-harvest methods. Bulletin OILB/SROP 30: 423-426.
Wills RBH, Scott KJ, Lyford PB, Smale PE 1976. Prediction of bitter pit with calcium content of apple fruit. New Zealand Journal of Agricultural Research 19: 513-519.

Wojcik P 1999. Effect of boron fertilization on uptake and distribution of selected mineral nutrients in 'Els tar' apple trees. Journal of Fruit and Ornamental Plant Research 7: 119131.

Wojcik P, Borowik M 2013. Influence of preharvest sprays of a mixture of calcium formate, calcium acetate, calcium chloride and calcium nitrate on quality and 'jonagold' apple storability. Journal of Plant Nutrition 36: 2023-2034.

Wojcik P, Cieslinski G, Mika A 1999. Apple yield and fruit quality as influenced by boron applications. Journal of Plant Nutrition 22: 1365-1377. 